\title{
Assessment of speech and communication disorders in preschool children with autism
}

\section{Ocena zaburzeń mowy i komunikacji u dzieci $z$ autyzmem w wieku przedszkolnym}

\author{
Barbara Szukiel1,3 (D), Piotr Sobaniec²,3 (D) Ewelina Batruch²,3 (D), Urszula Kruk ${ }^{3}$ (D), \\ Joanna Łotowska ${ }^{4}$ iD \\ ${ }^{1}$ Department of Pediatric Neurology and Rehabilitation, Medical University of Białystok, Waszyngtona 17 Str., 15-274 Bialystok, Poland \\ ${ }^{2}$ Neuromaster - Institute of Neurophysiology, Gliniana 14 Str., 15-068 Białystok, Poland \\ 3 “Hope and Opportunity” Foundation, Gliniana 14 Str., 15-068 Białystok, Poland \\ ${ }^{4}$ Department of Medical Pathomorphology, Medial University of Bialystok, Waszyngtona 13 Str., 15-269 Białystok, Poland
}

DOI:10.20966/chn.2018.54.416

\section{ABSTRACT}

Introduction: Most of the published studies about the speech therapy of children with autism are focused on the phonetic aspect of speech. Aim of the study: Assessment of a wide range of communication disorders using effective diagnosis and speech therapy. Material nad methods: The study group included 96 preschool (3-6 years) children diagnosed with autistic spectrum disorder (ASD). We assessed speech using our own questionnaire with elements of the standardized Language Development Test for children aged 4-8 years. Results: Significant deficits were observed in nonverbal communication use. Multiple dyslalia was the most common speech defect observed in the remaining children ( $27 \%$ of the group). Tongue and lip functions were below normal. The level of naming was lower compared with understanding for almost all investigated speech parts: nouns by $16.7 \%$, verbs and adjectives by $11.4 \%$, prepositions by $4.2 \%$. The children displayed significantly impaired abilities to use their native language syntax with $20.8 \%$ of children able to form grammatically correct sentences. Impaired pragmatic communication skills were observed in most cases. Conclusion: Thorough assessment of communication skills in children with autism revealed impairment of all speech aspects, i.e. phonological, semantic and syntactic already at preschool age. Due to the wide range of communication disorders, a speech therapist should be an important member of the interdisciplinary team and have a significant impact on the work of other therapists. A thorough diagnostic assessment of speech is crucial for the development of an effective therapeutic program and it should not be limited to the phonetic aspect of language.

Keywords: speech therapy, autism, ASD, therapy, diagnosis, communication

\section{STRESZCZENIE}

Wstęp: Większość opublikowanych dotychczas prac badawczych o terapii mowy u dzieci z autyzmem skupia się na fonetycznym aspekcie mowy. Cel pracy: Ocena szerokiego zakresu zaburzeń komunikacji z wykorzystaniem efektywnej diagnozy i terapii logopedycznej. Materiał i metoda: Grupa badawcza obejmowała 96 dzieci w wieku przedszkolnym (3-6 lat) z diagnozą ASD. Ocenialiśmy mowę, używając autorskiego kwestionariusza, który zawierał elementy standaryzowanego Testu Rozwoju Mowy dla dzieci w wieku 4-8 lat. Wyniki: Znaczące deficyty zaobserwowano w komunikacji niewerbalnej. Dyslalia wieloraka była najczęściej występującą wadą wymowy w badanej grupie (27\%). Sprawność narządów artykulacyjnych była poniżej normy. Poziom umiejętności nazywania był znacznie niższy niż rozumienia nazw w odniesieniu do wszystkich badanych części mowy: rzeczowniki o 16,7\%, czasowniki o 11,4\%, przystówki o 4,2\%. Znacząco zaburzone były umiejętności posługiwania się składnią języka ojczystego, 20,8\% dzieci potrafita tworzyć poprawne gramatycznie zdania. Większość badanych prezentowała istotne zaburzenia pragmatycznych umiejętności językowych. Wnioski: Dokładna ocean umiejętności komunikacyjnych u dzieci z autyzmem ujawniła zaburzenia wszystkich aspektów mowy, w tym fonologicznego, semantycznego, składniowego, już w wieku przedszkolnym. Ze względu na szeroki zakres zaburzeń komunikacji, logopedzi powinni być istotnym członkiem interdyscyplinarnego zespołu terapeutycznego i mieć ważny wpływ na pracę innych specjalistów. Szczegółowa diagnoza logopedyczna jest niezbędna dla tworzenia efektywnych planów terapeutycznych i nie może ograniczać się do oceny fonetycznej strony języka dzieci z autyzmem.

Słowa kluczowe: logopedia, autyzm, ASD, terapia, diagnoza, komunikacja

\section{INTRODUCTION}

A child's speech development depends on their general psychosomatic and social development. Speech development is a multistage process where the different developmental stages are not closely related to age, but rather determine the level of language development.

Disorders in social functioning due to lack of communication are the most serious problems for people with au- tism and their families. Impaired cognitive processes are a consequence of anomalies in the language acquisition process (language as a tool for describing and understanding the world and for personality development). Their impaired communication skills are due to difficulties in the perception of the functioning of another person as a complex object. A child with autism is unable to integrate individual elements of perception of a given person into an 
overall context; therefore, interaction and communication do not correspond to general patterns $[1,2]$

Although some individuals with Autism Spectrum Disorder (ASD) achieve a certain level of speech and language skills with age, speech regression can be observed in children who develop autism after the age of 12 months. In such cases children start to develop communication skills but later gradually lose their acquired skills, are no longer able to establish contacts and their vocabulary becomes limited. The regression in communication skills is most likely to occur around 15-19 months of age and affects up to $15-30 \%$ of children with autism [3, 4].

Speech development in children with autism is significantly delayed and impaired compared with normal age-appropriate development. Although the signs of developmental disorders are already present in the youngest children with ASD it is very hard to identify them early. The children rarely make eye contact with their mothers, sporadically give a 'social smile' or respond to their name and their babbling is very poor or absent $[5,6]$.

In the later period children who develop verbal speech display echolalic disorders, incorrect use of pronouns, literalness and neologisms. They repeat questions when providing an affirmative answer and display phonic distortions [7, 8].

Most children with autism have difficulty using pronouns. This usually involves referring to oneself using other pronouns or referring to oneself as a stranger, e.g. by name. Children with autism sometimes use the 'you' pronoun when referring to a third person. Although difficulties using these parts of speech are also observed in healthy children, they persist for significantly longer periods and are more severe in children with functional disorders. Studies show that this phenomenon results from the relative use of these speech parts which indicates that when using a pronoun a child must adjust the pronoun to a given situation, i.e. understand who performs the activity and to whom it is addressed. Children with autism find this difficult due to their inflexible and schematic manner of language acquisition [5].

They typically exhibit difficulties with the pragmatic aspect of language. Even those with a high level of synthetic and semantic skills use and understand expressions literally. They correctly understand the meaning of words but are unable to focus on a speaker's intentions. This is due to the fact that an autistic child does not understand the relationship between the speakers, is unable to interpret a given situation based on the context or make a link between information about the participant of the interaction and its content. Children with ASD do not understand that one word can have a number of meanings or that one thing can be expressed in several ways. Therefore they have difficulties understanding irony, jokes, idioms and metaphors or accepting synonyms [7].

In addition to verbal speech disorders children with ASD also show impaired non-verbal communication. Children with autism do not show emotions in situations that elicit spontaneous facial reactions in their peers. They have a poor repertoire of gestures or do not use gestures at all to compensate for verbal communication deficiencies. The gestures are simple and aim to avoid or end social in- teractions. They rarely smile or nod; they usually express joy or approval by increased physical activity and stereotypical movements, such as hand clapping [3,9].

Individuals with autism do not use eye contact when communicating with those around them. This is due to their unfamiliarity with the fact that people use eye contact to transmit important messages, as well as difficulties interpreting transmitted signals or inability to respond to these messages [10].

Some children with autism do not use speech to communicate; however, their number is decreasing as shown by epidemiological studies. The absence of speech, which is defined as lack of use of single words (less than 5 words daily), presently occurs in $20 \%$ of children with ASD. Previous data indicated the lack of speech in $50 \%$ of children with autism $[11,5]$.

The multitude and variety of speech and communication disorders in individuals with ASD require a multidisciplinary diagnosis and therapy. The Department of Pediatric Neurology and Rehabilitation at the Medical University of Bialystok is an example of a center guided by the principle of interdisciplinary cooperation with an emphasis on speech therapy. More than 250 diagnosed autism cases allowed us to gain experience and implement therapeutic interactions. An accurate and thorough diagnosis is an essential element of effective speech therapy. The obtained language profile enables adjusting therapy to the deficit type and severity. The possibility of targeting interactions at the most serious problems of a child enables improving the level of their social functioning.

\section{AIM OF THE STUDY}

The aim of the study was to assess which speech and language difficulties are most common in children with autism. The therapeutic program should be tailored to each child. However, reviews such as this one enable directing the diagnostic process and provide speech therapists with guidance which skills and areas require special attention $[12,13]$.

\section{MATERIALS AND METHODS}

The study group included 96 preschool (3-6 years) children (78 boys and 18 girls) diagnosed with autism (Table I).

The studied children were aged 3 to 6 years old (preschool). Mean age was $4.26(\mathrm{SD}=1.04)$, which indicates that the age of $2 / 3$ of the children ranged between 3.3 and 5.3 years. Four-year old constituted the largest group.

We assessed speech using our own questionnaire which contained elements of the standardized Language Development Test for children aged 4-8 years.

The study began with an assessment of articulatory apparatus efficiency using the "Articulatory Motorics Assessment Cards" by Hanna Rodak. The test involved 12 tongue and 12 lip tests.

Active and passive speech resources were assessed using pictorial materials. Two-word commands and a text with a set of control questions allowed us to determine the level of understanding of longer statements.

We also analyzed the extent of the children's mastery of grammatical structures of their native language using 
Tab. I. Descriptive statistics for the age variable

Tab, I. Zaburzenia mowy i komunikacji w zależności od wieku

\begin{tabular}{ccccccc}
\hline Mean & Median & Mode & Mode number & Minimum & Maximum & Standard deviation \\
\hline $\begin{array}{c}4.26 \\
\text { (4 years and 3 months) }\end{array}$ & 4 & 4 & 35 & 3 & 6 & 1.04 \\
(1 year) \\
\hline
\end{tabular}

simple tests: dialog speech, picture description as well as narrating a 4-element picture story.

The study took place between June 1st, 2013 and December 15th, 2015 at the Department of Pediatric Neurology and Rehabilitation, Medical University of Bialystok.

We analyzed the obtained results in terms of quantity and percentage, and have presented them as figures and tables.

\section{RESULIS}

A speech assessment was performed to evaluate both the ability to use verbal speech with its individual elements as well as non-verbal skills.

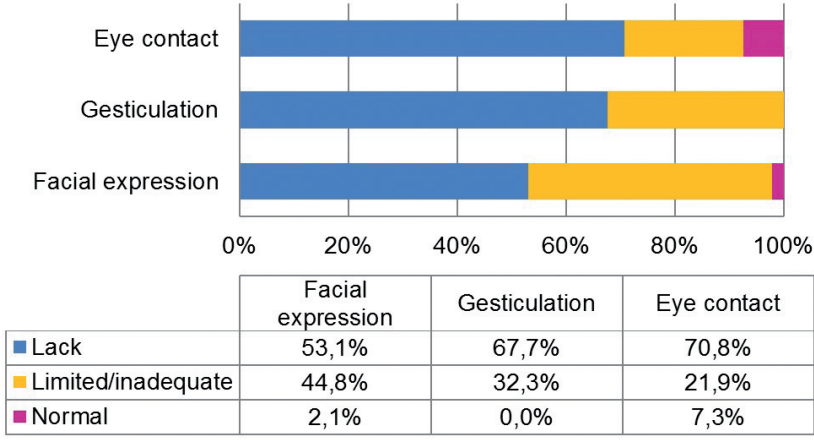

Fig. 1. Nonverbal communication skill in children with autism Ryc. 1. Wykorzystanie komunikacji nie werbalnej

Tab. II. Speech defects in children with autism

Tab. II. Występowanie zaburzeń mowy

\begin{tabular}{lrc}
\hline \multirow{2}{*}{ Speech defect } & \multicolumn{2}{c}{ Children with autism } \\
\cline { 2 - 3 } & \multicolumn{2}{c}{$\mathbf{N = 9 6}$} \\
\cline { 2 - 3 } & $\mathbf{n}$ & $\%$ \\
\hline $\begin{array}{l}\text { Lack of speech defects - } \\
\text { normal articulation }\end{array}$ & 12 & 12.5 \\
\hline Sigmatism & 11 & 11.5 \\
\hline Rhotacism & 4 & 4.2 \\
\hline Lack of verbal speech & $\underline{36}$ & $\underline{37.5}$ \\
\hline Kappacism + gammacism & 4 & 4.2 \\
\hline Multiple dyslalia & 26 & 27 \\
\hline Rhinolalia & 3 & 3.1 \\
\hline
\end{tabular}

Tab. III. Articulation organ efficiency in the studied children Tab. III. Sprawność organu mowy w badanej grupie

\begin{tabular}{lcccccc}
\hline & $\begin{array}{c}\mathbf{0 - 5} \text { points - significantly reduced } \\
\text { organ efficiency }\end{array}$ & $\begin{array}{c}\mathbf{6 - 8} \text { points - average degree } \\
\text { of organ efficiency }\end{array}$ & \multicolumn{2}{c}{$\mathbf{9 - 1 2}$ points - efficient organ } \\
\cline { 2 - 7 } & $\mathbf{n}$ & $\mathbf{N}$ & 65 & 67.7 & $\mathbf{n}$ & 12 \\
\hline Tongue & 19 & 19.8 & 73 & 76 & 10 & 12.5 \\
\hline Lips & 13 & 13.6 & & $\mathbf{N}$ & 10.4 \\
\hline
\end{tabular}

A total of $70.8 \%$ of children in the study group did not establish eye contact with the investigator, $21.9 \%$ of children only sporadically established eye contact. Only $7.3 \%$ of our patients had no difficulty in this respect.

Significant deficits were also observed in the use of gestures. Children made practically no use of this form of communication; $67.7 \%$ of our patients did not use gestures, $32.3 \%$ displayed a limited use of gestures or failed to properly match gestures to the content of their messages.

More than half (53.1\%) of children with autism did not use facial expression when communicating; $44.8 \%$ used it inadequately to the communicated message; $2.1 \%$ failed to properly and consciously use facial expression during interactions with the investigator.

As can be seen from the Table II., 37.5\% of children with autism did not use verbal speech (or only vocalized single, isolated phonemes). Speech defects were absent in only $12.5 \%$ of subjects; all native language phonemes were used correctly (considering the age of the children as well as developmental norms). Multiple dyslalia was the most (27\% of the group). We also observed isolated cases of sigmatism (11.5\%), rhotacism (4.2\%), kappacism/gammacism $(4.2 \%)$, and rhinolalia (3.1\%).

Tongue and lip function was below normal. The mean score was 7.57 out of a possible 12 points (average degree of organ efficiency) for the tongue and 7.47/12 for the lips.

Table IV shows differences in relation to active and paswith understanding for almost all investigated speech parts: nouns by $16.7 \%$, verbs and adjectives by $11.4 \%$, prepositions by $4.2 \%$, emotions by $13.6 \%$. When naming and identifying, the children coped best with naming objects, actions, and simple features. Only $18.7 \%$ of subjects could not identify nouns in the pictures or their real referent; $35.4 \%$ were unable to name these nouns. Emotions and abstract terms defining time and spatial relationships posed difficulty for most children: $66.7 \%$ were unable to verbally define or understand the position of objects relative to other objects.

A total of $37.5 \%$ of children with autism did not perform the picture storytelling test or tell a story based on a scene from an image (non-users of verbal speech). The remaining group was dominated by children using only common speech defect observed in the remaining children sive vocabulary. The level of naming was lower compared 
Tab. IV. Naming and understanding skills of children with autism Tab. IV. Nazywanie i zrozumienie

\begin{tabular}{|c|c|c|c|c|c|}
\hline \multirow{2}{*}{\multicolumn{2}{|c|}{ Tested skill }} & \multirow{2}{*}{\multicolumn{2}{|c|}{$\begin{array}{c}\text { Naming } \\
N=96\end{array}$}} & \multirow{2}{*}{\multicolumn{2}{|c|}{$\begin{array}{c}\text { Understanding } \\
N=96\end{array}$}} \\
\hline & & & & & \\
\hline & & $\mathbf{n}$ & $\%$ & $\mathbf{N}$ & $\%$ \\
\hline \multirow{2}{*}{ Objects } & Lack of skills & 34 & 35.4 & 18 & 18.7 \\
\hline & Normal & 62 & 64.6 & 78 & 81.3 \\
\hline \multirow{2}{*}{ Actions } & Lack of skills & 42 & 43.7 & 31 & 32.3 \\
\hline & Normal & 54 & 56.3 & 65 & 67.7 \\
\hline \multirow{2}{*}{ Features } & Lack of skills & 39 & 40.6 & 28 & 29.2 \\
\hline & Normal & 57 & 59.4 & 68 & 70.8 \\
\hline \multirow{2}{*}{ Spatial relationships } & Lack of skills & 57 & 59.4 & 53 & 55.2 \\
\hline & Normal & 39 & 40.6 & 43 & 44.8 \\
\hline \multirow{2}{*}{ Time relationships } & Lack of skills & 64 & 66.7 & 64 & 66.7 \\
\hline & Normal & 32 & 33.3 & 32 & 33.3 \\
\hline \multirow{2}{*}{ Emotions } & Lack of skills & 45 & 46.9 & 32 & 33.3 \\
\hline & Normal & 51 & 53.1 & 64 & 66.7 \\
\hline
\end{tabular}

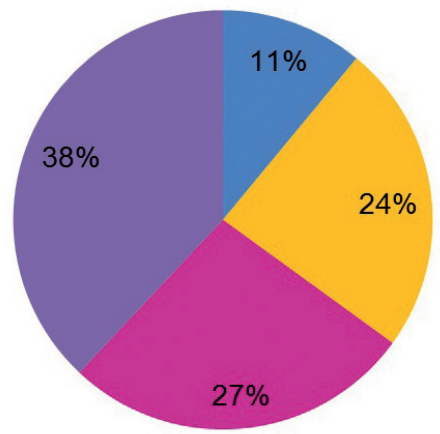

Complex sentences

Simple
sentences/gerund
clauses
- Single words

- Lack of speech

Fig. 2. Types of constructions used in narration and dialog speech Ryc. 2. Rodzaje konstrukcji słownych używanych w narracji i dialogu

single words and onomatopoeic phrases (27.1\%). Simple sentences and gerund clauses were used by $23.9 \%$ of subjects; $11.5 \%$ of children knew and used complex sentence structures in speech and picture descriptions.

The children displayed significantly impaired abilities to use their native language syntax, with $20.8 \%$ of children able to form grammatically correct sentences, $14.6 \%$ making single errors, and the remaining $64.6 \%$ using the wrong syntax. The most common errors were related to the syntactic concepts of government, agreement and belonging.

Our patients had significant difficulties using personal pronouns and adjusting the verb form to the person addressed. We observed improper use of personal pronouns in $74 \%$ of subjects.

Impaired pragmatic communication skills were observed in most cases. A total of $64.6 \%$ of children experienced difficulties related to all skill types, i.e. situational (adjustment of speech to the recipient and situation), social (adjustment of speech to the rank of recipient), and pragmatic (achieving the intended purpose of speech). Disorders in one of the above mentioned areas were observed in $21.9 \%$ of children.

\section{DISCUSSION AND IMPLICATIONS}

Linguistic skill development in children with ASD is characterized by difficulties in a number of areas. According to Lord and Rutter [14], 50\% of the population with autism experiences a complete lack of speech, while the remaining individuals display a specific language development. We observed the absence of verbal speech in $37.5 \%$ of children with autism. We also observed that the most common speech defect was multiple dyslalia (27\% of the group). This demonstrates the extent of pronunciation deficits in the study group, since the term dyslalia refers to an impairment of several series of sounds or a substantial part of sounds (distortion, substitutions, elision).

Normal function of the articulatory apparatus is crucial for active speech. Our tests revealed decreased function of the articulatory apparatus in children with autism. Literature data show that these problems may be associated with impaired perception and processing of sensory stimuli, poor sensory control of the speech apparatus, and a lack of ability to perform intentional, precise movements [15].

In our study, $70 \%$ of preschool-aged children did not make any attempt or made only sporadic attempts $(26.7 \%)$ to make contact with the therapist. In 2004, Coonrod and Stone [16] published a study based on recordings of children with autism in the first year of their lives. They found that a child's withdrawal from social company can be observed already during this period: deficits in social smile, pointing with the hand, looking at faces, emotional expression and maintaining attention.

Jones, Carr and Klin [17] compared two-year old children with autism to their healthy peers by exposing them to video recordings showing an actress' face trying to encourage the children to play. Patients with autism were much less likely to look at the eyes of the presented person. Furthermore, children showing poor social functioning looked at the actress' eyes for a much shorter time. In our study, children with autism also showed significant abnormali- 
ties in maintaining eye contact with the investigator. Other aspects of non-verbal communication, such as facial expression and gestures, were also significantly impaired.. Schultz et al. [18] showed that brain areas specializing in the processing of facial information do not function properly in patients with autistic disorders.

This is also associated with difficulties naming and reading emotions. We assessed this ability using pictures and photographs that depict human faces expressing basic emotions. A total of $46.9 \%$ of children with ASD were unable to name the presented emotions and $33.3 \%$ could not identify the picture showing the emotional state named by the investigator.

There are several hypotheses explaining this disorder. The first is the weak central coherence theory which states that children with autistic disorders focus on details when processing information. As a result, they find it difficult to understand the entire context of these details. Facial expression is perceived by individuals with autism as a set of changes they neither understand nor are able to compare. Another concept refers to the mind-blindness theory of ASD. According to this theory, patients with autism are characterized by cognitive blindness to the mental states of co-participants of social interactions as well as a lack of ability to interpret facial expressions [18].

In our study, we thoroughly investigated the relationships between the active and passive vocabularies of children with autism. We demonstrated that their active vocabulary is smaller than their passive vocabulary. We observed significant difficulties in naming and identifying time and spatial relationships. The obtained results contradict Pisula's [5] opinion that children with autism use much more words than they understand. The author relied on studies showing that speech expression and understanding develop with age in children with ASD. She believes, however, that the problems in understanding the meaning of words are greater than the difficulty of their use. Our analysis showed significantly better results related to the understanding the meaning of words for all evaluated categories.

A total of $80 \%$ of our participants used grammatical structures that were incorrect in terms of syntax and very poor. A group of scientists from the University of Massachusetts [19] attempted to explain this phenomenon by comparing children who were beginning to speak, regardless of age. The assessment included children with autism, Down syndrome as well as children developing in accordance with the developmental norm. They found that the sequence of syntactic and morphological structures in the course of speech development was the same in all groups. Therefore, they concluded that the formal aspects of language acquisition are not significantly impaired in autism. The study found, similarly to our findings, significant deficits in the manner of using language by children with autism.

Particular attention has been paid by other authors to difficulties using personal pronouns and matching verb forms to the person performing the activity. Our patients had the greatest difficulty with using different forms of the 'I' pronoun. They often replaced it with the pronouns 'you', 'he/she' or used their own names. There are hypotheses in the literature [6] on the relationship between impaired use of personal pronouns and serious problems with own identity of individuals with autism. However, there are no studies supporting these theories.

We have found, based on observations of children with autism included in this study, that impaired pragmatic language skills, i.e. using the language to communicate with the environment, is the factor that hinders their communication the most. This is probably due to the fact that people with autism often have problems in understanding the social context they are in, which results in a very low level of awareness of the adequacy of their responses.

All the above discussed factors significantly prevent children from verbal interaction with the surrounding world. Only $30 \%$ of our non-verbal patients used alternative methods of communication. Augmentative and Alternative Communication (AAC) is not an end in itself, but a tool to help acquire language and, above all, communication skills. This is confirmed by studies conducted by Millar, Light and Schlosser [20] who demonstrated that no limitation in the use of speech was observed in any of the 67 subjects following the introduction of an alternative method. The development of communication, including verbal communication, was observed in $89 \%$ of the subjects, and lack of improvement was observed in only $11 \%$.

Our study confirmed the extent of speech disorders in young children with autism. Language deficits in the control group were evident in all aspects: morphological, syntactic, lexical, semantic, pragmatic, and phonological (frequently disregarded in these types of papers). Preschool children do not use or deform most phonemes due to difficulties in social functioning and later language acquisition. In each case, therapy should focus on difficulties characteristic for each child proportionally to the extent of these problems. A thorough assessment of all the described components of language is crucial for successful speech therapy.

\section{CONCLUSIONS}

1. Thorough assessment of communication skills in children with autism revealed impairment of all speech aspects, i.e. phonological, semantic and syntactic, already at preschool age.

2. Verbal speech disorders were not in any way compensated by non-verbal speech. Therefore, speech therapy should not be limited to speech but aim to develop broadly understood communication.

3. Due to the wide range of communication disorders, a speech therapist should be an important member of the interdisciplinary team and have a significant impact on the work of other therapists.

4. A thorough diagnostic assessment of speech is crucial for the development of an effective therapeutic program and it should not be limited to the phonetic aspect of language. 


\section{ACKNOWLEDGEMENTS, COMPLIANCE WITH ETHICAL STANDARDS:}

\section{Conflict of Interest:}

Author Barbara Szukiel ${ }^{1}$ declares that she has no conflict of interest.

Author Piotr Sobaniec ${ }^{2,3}$ declares that he has no conflict of interest.

Author Ewelina Batruch ${ }^{2,3}$ declares that she has no conflict of interest.

Author Urszula Kruk ${ }^{3}$ declares that she has no conflict of interest.

Author Joanna Łotowska ${ }^{4}$ declares that she has no conflict of interest.

\section{Ethical approval:}

All procedures performed in studies involving human participants were in accordance with the ethical standards of the institutional and/or national research committee and with the 1964 Helsinki declaration and its later amendments or comparable ethical standards. The Bioethics Committee of the Medical University of Bialystok approved the study.

\section{Informed consent:}

Informed consent was obtained from all individual participants included in the study.

\section{REFERENCES}

[1] Cieszyńska J.: Od zabawy I nauki czytania do system językowego. Od języka do społeczności. Logopeda 2007; 1, 4: 6-28.

[2] Zima J., Kokot M., Rymaszewska J.: Rehabilitacja dzieci autystycznych oraz z zespołem Downa a poczucie obciążenia opiekunów. Fizjoter 2011; 19, 3: 9-18.

[3] Gorczyca P., Kapinos-Gorczyca A.: Wczesne wykrywanie autyzmu dziecięcego - analiza pierwszych nieprawidłowych zachowań i objawów. Klin Pediatr 2007; 15, 4: 454-456.

[4] Kenworthy L., Wallace G.L., Powell K., et al.: Early language milestones predict later language, but not autism symptoms in higher functioning children with autism spectrum disorders. Research in Autism Spectrum Disorders 2012; 6: 1194-1202.

[5] Pisula E.: Autyzm. Od badań mózgu do praktyki psychologicznej. Gdańskie Wydawnictwo Psychologiczne, Sopot 2012
[6] Frith U.: Autyzm. Wyjaśnienie tajemnicy. Gdańskie Wydawnictwo Psychologiczne, Gdańsk 2008.

[7] Kaczmarek B.: Nie jak, ale dlaczego? 0 własnym języku dzieci z autyzmem. Oficyna Wydawnicza "Impuls", Kraków 2009.

[8] Młynarska M.: Autyzm w ujęciu psycholigwistycznym. Terapia dyskursywna a teoria umysłu. Wydawnictwo Uniwersytetu Wrocławskiego, Wrocław 2008

[9] Matson J.L., Kozlowski A.M., Matson M.M.: Speech deficits in persons with autism: Etiology and symptom presentation. Research in Autism Spectrum Disorders 2012; 6: 573-577.

[10] Pisula E.: Rodzice wobec zaburzeń zdolności komunikacyjnych u dziecka z autyzmem. [w:] Człowiek wobec ograniczeń. Niepełnosprawność, komunikowanie, diagnoza, terapia. Tarkowski Z., Jastrzębowska G. [red.], Wydawnictwo Fundacji "ORATOR", Lublin 2002.

[11] Lord C., Shulman C., DiLavore P.: Regression and word loss in autistic spectrum disorders. J Child Psychol Psychiatry 2004;45: 936-955.

[12] Waś A., Sobaniec P., Kiryluk B., et al.: Czy to autyzm? Trudności w diagnozie. Neurol Dziec 2011; 20: 105-110.

[13] Olchowik B., Otapowicz D., Waś A., et al.: Klinika Neurologii I Rehabilitacji Dziecięcej - przykład współpracy interdyscyplinarnej. Neurol Dziec 2011; 20: 159-162.

[14] Lord C., Rutter M.: Autism and pervasive developmental disorders [w:] Child and adolescent psychiatry: Modern approaches. Rutter M, Taylor E, Hersov B. [red.], Blackwell, Oxford 1994.

[15] Blok B., Brzeska Z., Marszałek M.: Poradnik przygotowany przez Stowarzyszenie Pomocy Osobom Autystycznym w Gdańsku w ramach program "Zrozumieć Autyzm" - Program Pomocy Osobom Autystycznym z Terenów Wiejskich oraz Ich Rodzinom. Wydawnictwo Harmonia, Gdańsk 2013.

[16] Coonrod EE., Stone WL.: Early Concerns of Parents of Children with Autistic and Nonautistic Disorders. Infants and Young Children 2004; 17, 3 : 258-268.

[17] Jones W., Carr K., Klin A.: Absence of preferential looking to the eyes of approaching adults predicts level of social disability on 2-year-old toddlers with autism spectrum disorder. Archives of General Psychiatry 2008; 65: 946-954.

[18] Schultz RT., Gauthier I., Klin A., et II.: Abnormal ventral temporal cortical activity during face discrimination among individuals with autism and Asperger's syndrome. Archives of General Psychiatry 2000; 57: 331-340.

[19] Tager-Flusberg H., Calkins S., Nolin T., et al.: A longitudinal study of language acquisition in autistic and Down syndrome children. J Autism Dev Disor 1990; 20: 1-21.

[20] Millar D., Light J., Schlosser R.: The impact of augmentative and alternative communication intervention on the speech production of individuals with developmental disabilities: A research review. J Speech Lang Hear Res 2006; 49: 248-264.

\section{Corresponding author:}

Barbara Szukiel, The Medical University of Bialystok Children's Clinical Hospital, Department of Pediatric Neurology and Rehabilitation, Waszyngtona 17 Str. 15-276 Białystok, Poland. Email: bt27@02.pl 